\title{
ISLAMIC TRADITIONS OF WATER-SUPPLY CONSTRUCTION IN THE CRIMEA
}

\author{
N.M. Akchurina-Muftieva \\ Crimean Engineering and Pedagogical University \\ Simferopol, Russian Federation \\ akchurina_05@mail.ru
}

\begin{abstract}
Research objective: To reveal Islamic traditions for creating water sources and fountains in the Crimea, their stone-cutting ornamentation, and to discuss their typology according to their purpose and volume-compositional solutions.

Research materials: The art of the construction of Crimean fountains and their semantic aspects were analyzed in the publications of M. Ginzburg and A.N. Malinovskaya. Ornamentation and semantics of stone plastics of Muslim structures (fountains and gravestones) were studied by S.M. Chervonnaya and E.A. Aybabina. The issues of organization, typology, ornamentation and semantics of water sources of the $15^{\text {th }}-19^{\text {th }}$ centuries have not been practically analyzed so far. On the basis of a small number of extant buildings, as well as archival materials and descriptions of travelers, the author of the article offers an insight into the variety of forms and ornamentation of waterworks of the indicated period.

The novelty and the results of the research: The study of traditional forms of Crimean Tatar artistic creativity contributes to our wider knowledge of the culture of the Crimea, developed at the peninsula since ancient times. Forced relocation, long-term actual prohibitions of the existence and development of the Crimean Tatar art, loss and destruction of its material remains and documents, and the influence of the cultures in the areas of deportation led to the loss of the ethnic memory of the people, as well as reliable and complete information about their traditional art, its symbolism and ornamentation. The identification of the specific characteristics of the artistic language and style, and the recovery of forgotten technologies, encourages a deeper and complete understanding of the genuine folk art and the revival of folk traditions in contemporary art.
\end{abstract}

Keywords: water resource, fountains, Crimea, Islamic traditions, cutting décor

For citation: Akchurina-Muftieva N.M. Islamic Traditions of Water-Supply Construction in the Crimea. Zolotoordynskoe obozrenie=Golden Horde Review. 2019, vol. 7, no. 4, pp. 663-673. DOI: 10.22378/2313-6197.2019-7-4.663-673

The centuries-old cultural tradition of the Crimean Tatars made considerable influence on the art of multiconfessional population of the Crimea. At present, it is in need of restoration of long-ago forgotten technologies, including study, recreation and revelation of its specifics, peculiarities of its artistic language and style, and renewal of folk traditions in modern arts.

Islamic traditions of water sources and fountains are part of such traditions. In all Muslim countries, especially those in the desert, water had great significance, especially the "clean", running water.

The fountains were made to commemorate the memory of the deceased relatives and perished warriors, to keep the memory of the important events in life of those who built them, or simply for the benefit of the community. The arid Crimean Peninsula, which was always short of water, was not an exclusion from these traditions. Around 
120 fountains were built in Bakhchisaray only, where the water was taken from 32 springs, and around 100 fountains existed in Feodosia. There were many of them in Stariy Krim, Karasubazar, in Simferopol and in other cities and villages. Some of them were built by the funds of the khans, or other wealthy citizens. In Bakhchisaray, for instance, the fountains were built near the main city gates, on the city markets and near mosques. They were sustained by the taxes of leased shops, incomes from the fruit gardens in a village of Suren and from the inn in Bakhchisaray ${ }^{1}$.

In the Crimea, the refined water springs were built in walls of the buildings, or sometimes separately. There were four different types of them, depending on their usage: for example, cheshme was the small source of drinking water; abdest fountains were intended for ritual washing before prayer; fountain yards or pavillions were the cozy springs inside the buildings, made for the resting; sebil were "sacred", paradise springs.

The traditional and the most often used fountains were cheshme. They were always the center of social life in the Crimean villages. They were built not only in the interior of the peninsula, but also along the roads on the south shore of the Crimea. The women that were coming to the fountains to take water, discussed all kinds of news, while the young men looked for a bride among the girls. "A small stone wall, resembling a fireplace, was simply put to the steep mountain slope; a thin metal tube was thrusted into it and water ran or dripped through it. On some fountains were Turkish inscriptions in stone, containing the written name of a person, a benefactor, who made the fountain for the thirsty travelers passing by. Despite being not very eye-catching, the fountain is very beneficial in the arid conditions, which is the curse of the Crimea, especially during the hot summer. Some of the fountains supply water for the whole area" [1, p. 192].

Cheshme water sources were built in a form of vertical stelae, about 1.5-2 meters high, with pointed arch niches. A small stone reservoir was usually built in front of them, in order to accumulate water. Very often, a stone plate, with engraved Arabic ornamental writings, bearing the name of its founder, was attached above it (ill.1). The front wall of the reservoir was sometimes decorated in the form of rosette with geometrical or floral ornaments. The tradition of construction of such springs can be traced until the late $19^{\text {th }}$ century.

The influence of Muslim architecture is attested by the $15^{\text {th }}$ century fountain, built by the Armenians in Feodosia at the foot of the Mithridat mountain, and restored in the $16^{\text {th }}$ century. The rectangular wall of the fountain has a niche in the form of the pointed arch and three carved rosettes above it. The middle rosette represents a solar sign, while the side rosettes stand for the star of David.

Two fountains of drinking water with arch niches, decorated in carved stone, were built in the $17^{\text {th }}-18^{\text {th }}$ century in the Ambassadors' courtyard of Bakhchisaray palace. In the niches of one of the fountains, a tree resembling palm was carved (ill.2). Water runs from its base into the stone reservoir, decorated with floral ornaments. The stone reservoir represents the Earth, which came to life and blossomed in rich plants: the palm tree, which provides tasty fruits and water, literally illustrates the words from the Koran how Allah had given water to people, revived the Earth, and grew date fruits.

\footnotetext{
${ }^{1}$ Archiv SM ARK [Council of Ministers of the Autonomous Republic of Crimea Archive]. Simferopol, f. 489, inv. 1d.650, v. 2-8. (In Russian).
} 


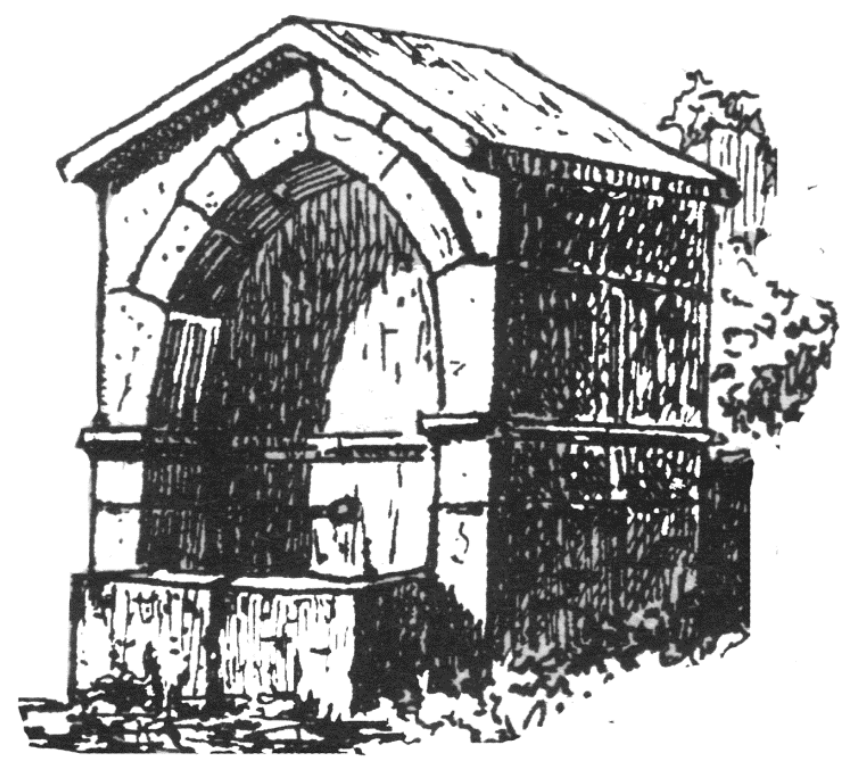

III. 1. Cheshme - traditional and the most widespread spring in the villages and along the roads in the Crimea

The fountains of Bakhchisaray Palace resemble the fountains made by Turkish nobles (the $18^{\text {th }}$ century fountains at the Sultanahmet square in Istanbul) [6, ill. 14, 73]. However, the Crimean Tatar fountains are more modest in decoration and smaller in form, expressing the symbol that gives life to living beings, rather than pompous construction that glorifies its creator.

Not far from Bulgakov's mosque in Kokkoz village, a fountain survived, built by the funds of Bulgakov bey in 1883 from thick limestone, and is still functioning. The fountain represents a small reservoir with almost two meters high stelae, pincer-like top and arch niche. On the diorite construction board, which was made on the upper part of the niche, it is written in Russian and Arabic language: "This fountain was built by the court counselor and prince Ali Bey Bulgakov on his own expense and for the common benefit".

In 1888, in Feodosia a fountain was built, bearing the name of artist I.K. Ayvazovsky, who projected it and secured the funds for its construction (ill. 3). Its volumetric proportions resemble the Turkish fountain in Istanbul, dedicated to the memory of Ali Pasha Hekimoglu [6, ill.1]. The square fountain is covered by hipped roof with big figure cornice. The roof is completed by five semi-cupolas (a tribute to Orthodoxy), the corner overhangs are decorated by figure plafonds, while the bottom is lined by wooden laths (the same as the cornice of Bakhchisaray palace). It is painted and, on the perimeter, framed by wide strap of carved wood. The bottom of arch niche is decorated by stalactites, whereas the top is decorated by wedge shaped archivolt and ornament. The marble columns were made in the square cuts of the façade's main corner. The other facades have niches with semicircular completion. Under the cornice, deepening marble rosettes are set in the form of hexahedron. On the basement level, water runs into the right-angled pools from the holes on four sides in the niches. 
The Crimean Tatar traditions of fountain construction were used in the $19^{\text {th }}$ century by the architect P. Krasnov, during the building of Yusupov's palace at the village of Kokkoz. At the main entrance of the building, he made a very original wall fountain "The Blue Eye", designed in the form of a pointed niche. The niche is faced with majolica tiles of different shades of greenish color, imitating the Crimean Tatar carpet - kilim (ill. 4). The upper part of the arch is magnificently decorated by ornamented rectangular edging in blue tones. In the center of the niche there is a ceramic portrayal of stylized blue eye, from which a stream of spring water runs into reservoir, the water being brought here from the mountain spring. The fountain is made in modern style, and the concept of blue eye comes from the legendary name of the village (in Crimean Tatar language "Kokkoz" means "The Blue Eye"). Another fountain was built near the gates, made of cut-off diorite blocks in the form of 3 meters high stele. The fountain is faced with tiles, has a semi-circular niche, water cannon, a small reservoir and a platform three steps high.

Characteristic traits of the cheshmes built in the $15^{\text {th }}-19^{\text {th }}$ centuries are: carved rosettes with geometrical and floral ornaments, made above pointed arch niche, and carved writings and epitaphs from the Koran, interlaced with floral ornaments, made in "sulus" writings.

The second group were the fountains intended for ablution (abdest) before the prayer. As a rule, they were built near mosques where Muslims usually prayed. They were mainly erected separately and had round, very often octahedron or hexahedron forms of reservoir. The fountain built to the left of Khan's mosque in Bakhchisaray may serve as an example. A pool, about 3 meters in diameter, covered with cupolas, was situated in the square yard, paved with tiles. Its bottom was decorated with carved tiles of white marble, metal tubes were thrust through them and clean water poured into the round marble chute. Such fountains appeared in the Crimea at the time when the first mosques were built $[3, \mathrm{p} .41]$ and since then, they became its most important attribute.

Another form were the fountain yards or the pavilions. They were widely used inside the buildings and yards in the palaces and houses of rich people (ill. 5). The cozy springs created "a peculiar shady atmosphere around the life-giving drops of water, protecting this small oasis from the bright sunrays and noisy shouts. When entering from the turmoil of city streets into the fountain yard...you cannot see anything at first in this cool shade. You will never get the whole image of it at once. Gradually, moment after moment, you'll see one detail after another. Everything here is made in the way as it was supposed to influence our sense perceptions, not only by internal images, but by the musical movements of water drops as well, the charm of the coolness itself, picturesque of obscure darkness" [2, p. 216].

A fashion of making of fountain yards was established at the time of the first Crimean rulers - khans, who relied on Constantinople. In Solkhat, water tubes made of pottery, leading to the city fountains were found. The first mention of such fountains was in Evliya Çelebi's travelogue, who had visited Ashlama gardens in Ashlama Saray palace, which existed at the end of the $15^{\text {th }}$ century in Salachik. Many fountains decorated the small yards and gardens of Bakhchisaray palace. Until the end of the $19^{\text {th }}$ century these fountains were made in city parks of Karasubazar, Ak-mechet, Gezlev and other places.

The tradition of making fountains inside the buildings was widespread. They were made in various summer-houses, halls and sitting rooms. The fountains in 
summer-house (Alhambra) (ill. 6) and in the hall of Divan Bakhchisaray palace may serve as examples from $16^{\text {th }}-18^{\text {th }}$ centuries. In $19^{\text {th }}$ century there were two fountains in Yusupov's palace, one of which was a copy of Bakhchisaray Fountain of the Tears, and the other was put in the foyer, at the entrance of the park. All these fountains were mainly made from marble with the stone cutting ornaments, including the borders with floral motives. At the beginning of $18^{\text {th }}$ century, the bottom of the reservoirs, in some cases, was decorated by the pictures of different fishes and birds, for example, near the Pool's garden or near the chute of the fountain in the Ambassadors' courtyard. The central parts of the fountains were made in the form of a cypress, a blossoming bush, etc.

Before $18^{\text {th }}$ century a new type of fountains appeared in the Crimean Tatar arts - the Sebil fountains. In the architecture of the Arab countries Sebil represents a public spring, a fountain of clean water for drinking, made separately or as a wall construction with one or several arch niches, or even with the bowls of slowly running water into the basin. In Arabic language, the word means "a well" (spring) intended for public usage. It is derived from the verb "to make a donation for public use". Usually, such fountains were decorated by ornamental stone carving, coating in marble or ceramic mosaic, by calligraphic writings with prayers for the benefactor and with the quotations from the Koran, sayings or poetical couplets [4, p. 175-176]. Such fountains are known in Muslim world since $14^{\text {th }}$ century.

The Crimean architects created quiet, cool fountains - "a babbling saga from the stone" (M. Ginsburg), with slowly flowing streams of water and the fountains with symbols, reflecting the philosophy of the Koran, the theme of eternal existence. Thus, in the $18^{\text {th }}$ century, in the traditions of the architecture of the Ottoman Empire, appeared the new type of fountains, the "Golden fountain". In the rightangled portal, a shallow arch niche would be made, decorated at the top with carved stylized shell, plant ornament and stalactite belt. The gilded ornaments and relief inscriptions reveal the name of the fountain: Manzub - "Golden" (ill. 7).

In 1764, an Iranian artist-decorator made a walled Fountain of Tears to commemorate the memory of beautiful Dilyara Biketch. The artist used the language of symbols to show the endless grief for her death in the small architectural form. The cascade fountain at the entrance to Dilyara Biketch durbe, and a wall fountain in the Pool's patio, were built in the Sebil style.

In $19^{\text {th }}$ century their imitations were created: the fountain of tears in the palace of Empress Alexandra Fedorovna in Oreanda (architect A.K. Shtakenshneyder) and the fountain in the dinning-room of Yusupov's palace in the village of Kokkoz (architect N.P. Krasnov).

The main foundation of the Sebil fountains was vertical slab with pointed niche, with the bowls set there in graded order. Water, overflowing from one bowl into the other, fell into the rectangular or oval reservoir, in front of the fountain's slab. The portal, as a rule, was decorated by a carved plant ornament in the form of creeping shoots or flower pots. The motive of the flower-pots was widespread in the $18^{\text {th }}$ century in stone cutting, as well as in metal artworks. Probably, this tendency came from Turkey, where it was widespread, not only on the tiles of fountains and gravestones, but, since $18^{\text {th }}$ century, on the side planes of mimbars of mosques [7, ill. 226, 227; 6, ill. 14, 73].

In the small architectural forms of fountains, the masters of stone cutting widely used the language of symbols, such as lotus flowers with five petals, numerals 
such as three and nine; bowls that formed zigzag stairs; a snail form on the bottom of the pool and so on.

The typical example of the cascade Sebil fountains is the one in a Pool's patio in Bakhchisaray palace, consisting of marble slabs with 12 chutes, installed into the south wall. The fountain consists of vertical and horizontal planes. A movement of water symbolizes the birth, stormy but short life, consisting of divisions and generalizations, which is in contrast with eternal tranquility of smooth surface of the pool. Water from the fountain flows into the pool through a long canal, decorated by the cypresses - symbols of the afterlife. A snail form is also present - the symbol of eternity and doubts. The association with living and dead water is visible. As a result, the world is made of it. The main module of the whole artwork is the stream of water proportionate to a human being. The Crimean Peninsula is, by God's will, made surrounded by the sea, with scanty store of "live water". That is why the particular image of spiritual bodies was given to the wells and springs. On the basis of this, one can say that the Sebil fountain could be considered as the model of the Crimea [5, p. 36].

The epigraphy of fountains has the information on two levels: the fountain as a source of life and purification, whose sacral character goes back to the archaic lower levels of cultural Islam traditions; and the fountain as a book, understood only by the dedicated ones. Its external, wholesome image is interpreted as a page from the Koran with unvan (title, headline), crowned with alem (the half-moon on the top of the mosque used as a symbol of being above the world). The writings on the fountains from the Koran do not only stress the wholesome image of a book, but also carry it, similarly to the inscriptions on the buildings, weapons and household items.

The inscriptions on the fountains always finish with the word salsabil, which has several meanings. In Muslim mythology it is the name of the main spring in paradise (Koran 78:18). In the architecture of Egypt, Syria, Palestine and Andalusia from the $13^{\text {th }}-14^{\text {th }}$ century onwards, it is the system of cooling of the building interiors with water, based on the main principle of a slow runoff of a thin layer of water on a marble slab inserted into the wall, with the tilt of $15-30^{\circ}$. Water runs into decorative small canals, evaporates in them and thus cools the room. In the figurative meaning, the word salsabil denotes a paradise drink, a nectar.

Combining the sacred base of the Koran philosophy and poetic epigraphy, made of marble and carved with décor, the Crimean Sebil fountains serve as memorials, reminding about fleeting joys of life, inevitability of separation, and about the paradise bliss of righteous souls. In that aspect, they resemble each other and have spiritual kinship with the gravestones, whose upper part which was often carved in the shape of a bowl, always filled with rain water. The combination of planted greenery and water over the grave and decoration of stone fountains bring them closer in the symbolic meaning.

The carved décor of the fountains gradually changed, from rosettes with the Seljuk and the Golden Horde geometrical ornament of $15^{\text {th }}-16^{\text {th }}$ century, into the stylized plant ornament of $17^{\text {th }}$ century, and took the form of the magnificent baroque of $18^{\text {th }}-19^{\text {th }}$ century. In the esthetic expressiveness of buildings, we can trace the changes in the usage of limestone $\left(15^{\text {th }}-16^{\text {th }}\right.$ centuries), and (later) usage of colored and snow-white marble, coloring of certain ornament elements (in $17^{\text {th }}-18^{\text {th }}$ centuries), obligatory presence (during the $15^{\text {th }}-19^{\text {th }}$ centuries) of poetic epitaphs and formulas from the Koran, in the form of calligraphic ornaments. The inscriptions 


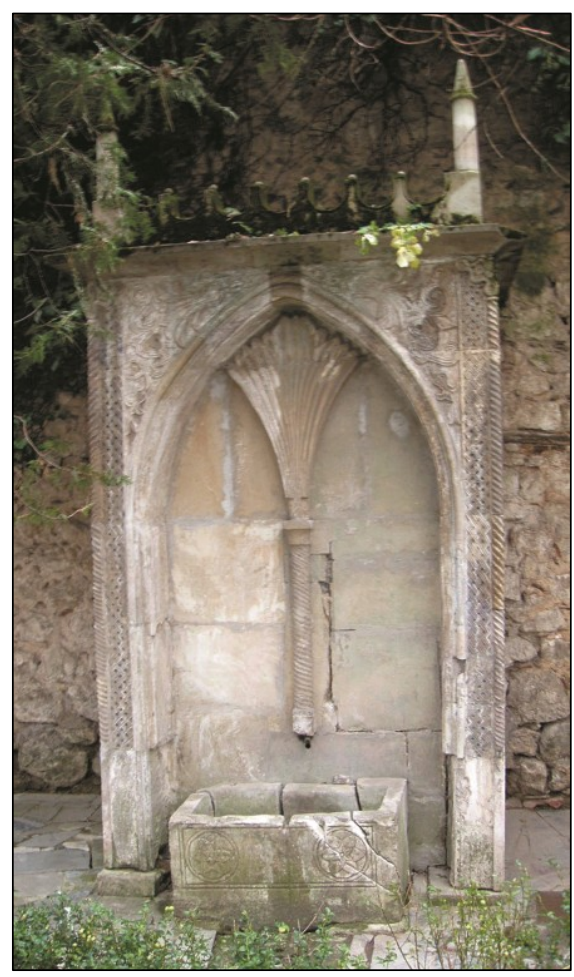

Ill. 2. The fountain with drinking water, built in the Ambassadors' courtyard in Bakhchisaray in $17^{\text {th }}-18^{\text {th }}$ century

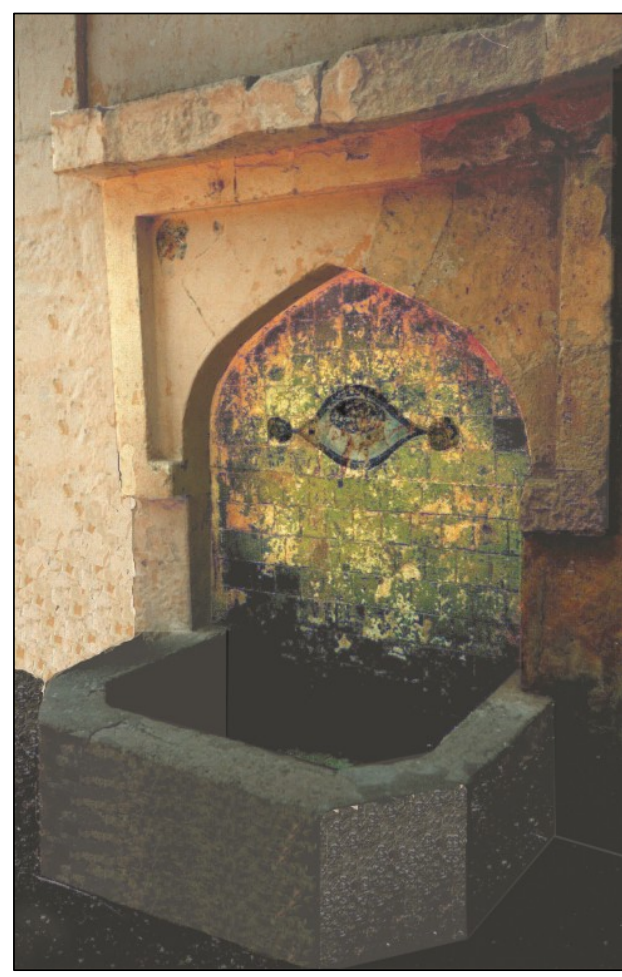

Ill.4. The "Kokkoz" fountain in the village of Kokkoz. $19^{\text {th }}$ century.

Architect - Krasnov N.P.

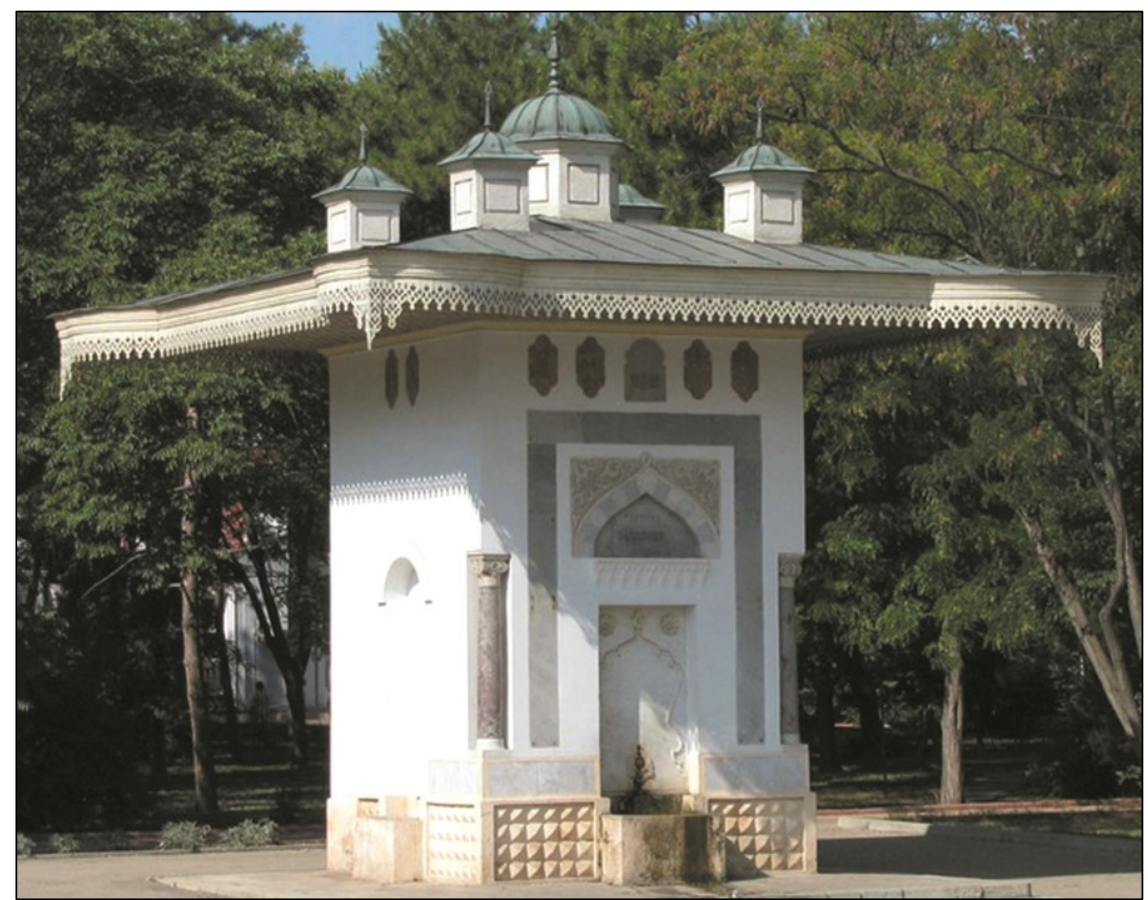

Ill. 3. The Ayvazovsky fountain. 1888. Theodosiya 


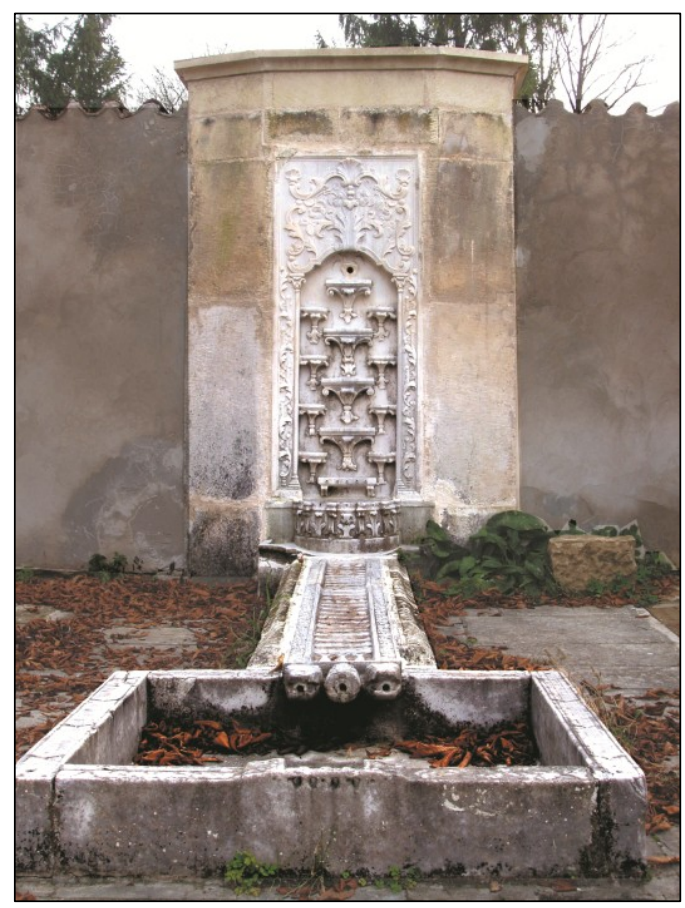

III. 5. The fountain yard in Bakhchisaray palace: fountain with two pools

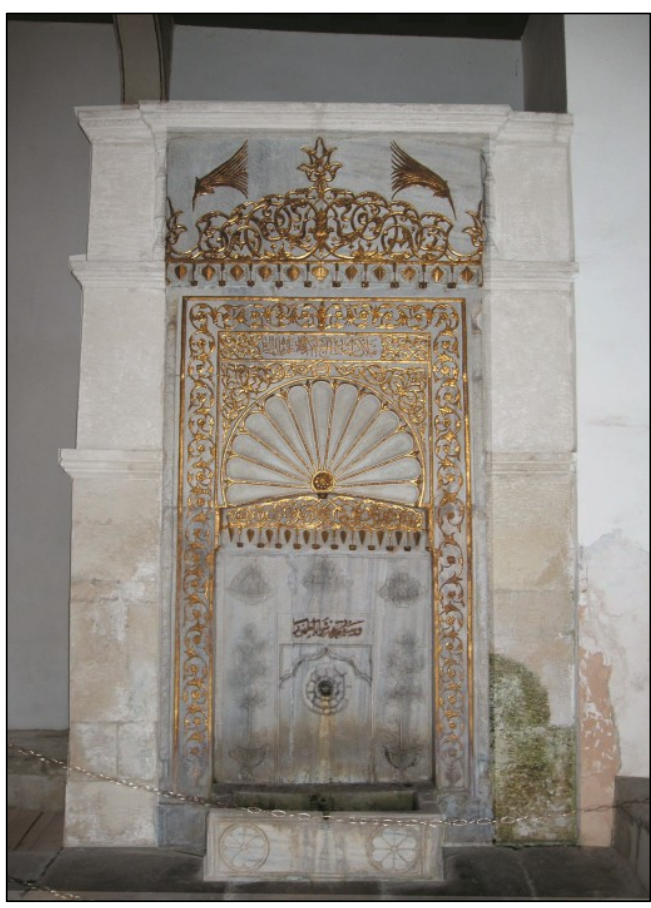

IIl. 7. The Golden fountain - Manzub. $18^{\text {th }}$ century. Bakhchisaray palace

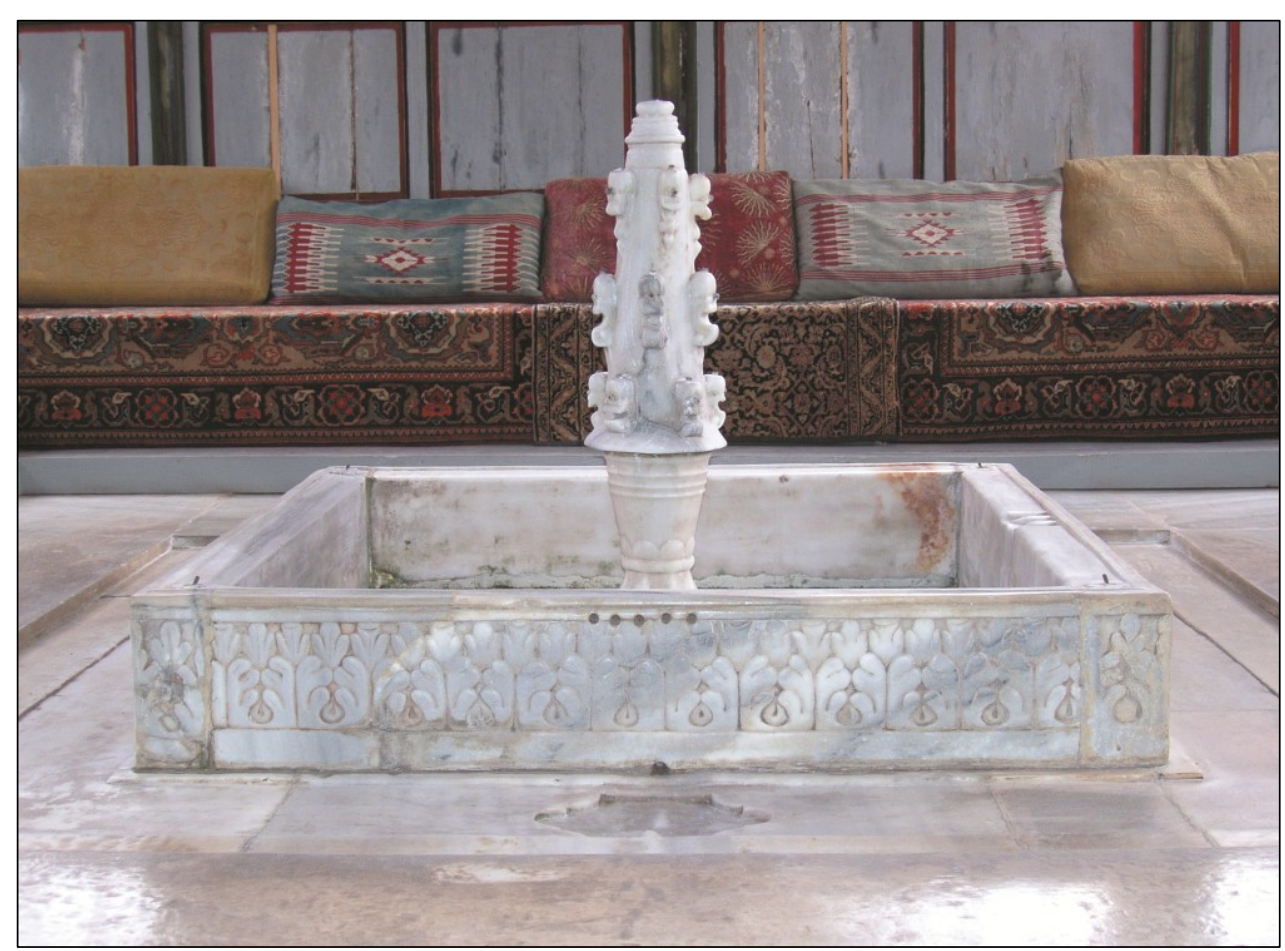

III. 6. The fountain from $17^{\text {th }}-18^{\text {th }}$ century in the summer-house (Alhambra). Bakhchisaray palace 
on the fountains could be very scanty and strict, only giving information about the date of its construction and the name of the person who did it. However, there are epitaphs that could strike us with its supreme poetical eloquence, and thus present an example of very high style of oriental poetry. Of course, the poetic pathos and magnificence of ornamental carved decorations and even the sizes of the construction, could depend on social position and desire of a customer, and individuality of a poet-engraver and his own skill. The texts, written on the fountains during the period of Crimean Khans, are more complicated than the epitaphs from the Golden Horde period. The creative work of hattats (calligraphers) - masters, at the same time doing the work of cutting the stone, and being "writers" and "scribers", could be reflected in their decoration of virtuoso calligraphic writings, made by the Golden Horde and classic "sulus" script, and later by "taalic" (a written script), woven into floral ornaments.

The skill of constructing fountains in the Crimea had a sacred basis, leaning on the fundamental layers of the Islamic philosophy, and a concept of the synthesis of artworks with surrounding nature. First of all, this is manifested in the religious perception of water as the source of life. Wide use of symbols allowed the devoted ones, to "read" the contents of the construction as a page from the Koran. At the same time, not only among the early, but also among the late fountains, Muslim symbolism is surprisingly intertwined with the pagan one, which could be seen in some of the motives, giving evidence about the mutual points of coincidence, complicated binding of Islamic arts with the Christian and Judaic symbolism and interpreted and reinterpreted Ancient mythology. Complex conditions of the Crimean Tatar people, stipulated the communion of many of their arts with arts of different neighboring peoples, and also with arts of other peoples from the shores of the Black Sea, thus giving way to the formation of very rich and original type of decorative arts among the Crimean Tatars.

\section{REFERENCES}

1. Voroponov O. Sredi krymskikh tatar [Among the Crimean Tatars]. Zabveniyu ne podlezhit (iz istorii krymskotatarskoy gosudarstvennosti i Kryma) [Must Not Consign to Oblivion (from the history of the Crimean Tatar statehood and Crimea)]. Kazan: Tatar Book Publ., 1992, pp. 162-193. (In Russian)

2. Ginzburg M.Ya. Tatarskoe iskusstvo v Krymu [Tatar arts in the Crimea]. Zabveniyu ne podlezhit (iz istorii krymskotatarskoy gosudarstvennosti i Kryma) [Must Not Consign to Oblivion (from the history of the Crimean Tatar statehood in the Crimea)]. Kazan: Tatarskoe knizhnoe Publ., 1992, pp. 209-217. (In Russian)

3. Krikun E.V. Pamyatniki krymskotatarskoy arkhitektury [The Monuments of the Crimean Tatar Architecture]. Simferopol: Krymuchpedgiz, 1998. 112 p. (In Russian)

4. Malinovskaya A.N. Semanticheskoe pole bakhchisarayskogo fontana («slez») v kontekste islamskoy traditsii [Semantic field of Bakhchisaray fountain ("of tears") in the context of Islam tradition]. Istoriya i arkheologiya yugo-zapadnogo Kryma [History and Archaeology of the South-west of the Crimea]. Simferopol: Tavriya, 1993, pp. 174-187. (In Russian)

5. Sheykh-Zade I. Sakral'nye motivy v krymskom iskusstve [Sacral Motives in the Crimean Tatar Art] Kasevet. 1995, no. 1, pp. 33-39. (In Russian) 
6. Varişta H. Örcün. İstanbul Çeşmeleri. Kabataş Hekimoğlu Ali Paşa Veydan Çeşmesi [Istanbul Fountains. Fountain Stone Hekimoğlu Ali Pasha Vey]. İstanbul, 1993. 94 p. (In Turkish)

7. Varişta H. Örcün. Türk el sanatlari [Turkish Handicrafts]. Ankara: Kültür Bakanliği, 1998. 178 p. (In Turkish)

About the author: Nuria M. Akchurina-Muftieva - Dr. Sci. (Art History), Professor, Department of Decorative Arts of the Crimean Engineering and Pedagogical University (8, Uchebnyj lane, Simferopol 295015, Russian Federation). E-mail: akchurina_05@mail.ru

\title{
ИСЛАМСКИЕ ТРАДИЦИИ СООРУЖЕНИЯ ВОДНЫХ ИСТОЧНИКОВ В КРЫМУ
}

\author{
Н.М. Акчурина-Муффтиева \\ Крымский инженерно-педагогический университет \\ Симферополь, Российская Федеращия \\ akchurina_05@mail.ru
}

Цель исследования: раскрыть исламские традиции организации водных источников и фонтанов в Крыму, их камнерезной орнаментики, рассмотреть типологию по назначению и объемно-композиционному решению.

Материаль исследования: вопросы искусства фонтанов Крыма и их семантического поля рассматривались в публикациях М. Гинзбурга и А.Н. Малиновской. Орнаментика и семантика каменной пластики мусульманских сооружений (фонтанов и надгробий) исследовались С.М. Червонной, Е.А. Айбабиной. Вопросы организации, типологии, орнаментики и семантики водных источников XV-XIX веков до настоящего практически не рассмотрены. По небольшому количеству сохранившихся сооружений, а также архивным материалам и некоторым описаниям путешественников автор статьи дает представление о разнообразии форм и орнаментации водных источников обозначенного периода.

Результаты и научная новизна: изучение традиционных видов крымскотатарского художественного творчества, способствует более широкому познанию культуры Крыма, развивающейся на полуострове с давних времен. Принудительное переселение, долговременный фактический запрет на существование и развитие, потеря и уничтожение вещевого и документального материала крымскотатарского искусства, влияние культур в местах депортации привели к утрате этнической памяти народа, достоверной и полной информации о традиционном искусстве, его символике, орна- 
ментике. Выявление специфики, характеристики художественного языка и стиля, восстановление забытых технологий способствует глубокому и полному пониманию подлинно народного искусства, возрождению народных традиций в современном искусстве.

Ключевые слова: водные источники, фонтаны, Крым, исламские традиции, резной декор

Для цитирования: Акчурина-Муффтиева Н.М. Исламские традиции сооружения водных источников в крыму // Золотоордынское обозрение. 2019. Т. 7, № 4. C. 663-673. DOI: 10.22378/2313-6197.2019-7-4.663-673

Сведения об авторе: Нурия Мунировна Акчурина-Муфтиева - доктор искусствоведения, профессор кафедры декоративного искусства ГБОУ ВО РК «Крымский инженерно-педагогический университет» (295015, переулок Учебный, 8, Симферополь, Российская Федерация). E-mail: akchurina_05@mail.ru 